\title{
Effect of sprouted barley grain supplementation of an herbage-based or haylage-based diet on ruminal fermentation and methane output in continuous culture ${ }^{1}$
}

\author{
A. N. Hafla, ${ }^{*}$ K. J. Soder, ${ }^{* 2}$ A. F. Brito, $†$ M. D. Rubano,${ }^{*}$ and C. J. Dell ${ }^{*}$ \\ *USDA-Agricultural Research Service, Pasture Systems and Watershed Management Research Unit, University Park, PA $16802-3702$ \\ †Department of Biological Sciences, University of New Hampshire, Durham 03824
}

\begin{abstract}
A 4-unit dual-flow continuous-culture fermentor system was used to assess the effect of supplementing 7-d sprouted barley (SB) or barley grain (BG) with an herbage-based or haylage-based diet on nutrient digestibility, volatile fatty acid (VFA) profiles, bacterial protein synthesis, and methane $\left(\mathrm{CH}_{4}\right)$ output. Treatments were randomly assigned to fermentors in a $4 \times 4$ Latin square design with a $2 \times 2$ factorial arrangement using $7 \mathrm{~d}$ for diet adaptation and $3 \mathrm{~d}$ for sample collection. Experimental diets were (1) $55.5 \mathrm{~g}$ of herbage dry matter $(\mathrm{DM})+4.5 \mathrm{~g}$ of SB DM, (2) $56.0 \mathrm{~g}$ of herbage DM $+4.0 \mathrm{~g}$ of BG DM, (3) $55.5 \mathrm{~g}$ of haylage DM $+4.5 \mathrm{~g}$ of SB DM, and (4) $56.0 \mathrm{~g}$ of haylage DM $+4.0 \mathrm{~g}$ of BG DM. Forages were fed at 0730, 1030, 1400, and $1900 \mathrm{~h}$, whereas SB and BG were fed at 0730 and $1400 \mathrm{~h}$. Gas samples for $\mathrm{CH}_{4}$ analysis were collected at 0725, 0900, $1000,1355,1530$, and $1630 \mathrm{~h}$ on d 8, 9, and 10. Fluid samples were taken once daily on $\mathrm{d} 8,9$, and 10 for $\mathrm{pH}$ measurements and for ammonia- $\mathrm{N}$ and VFA analysis and analyzed for DM, organic matter, crude protein, neutral detergent fiber, and acid detergent fiber for determination of nutrient digestibilities and estimation of bacterial protein synthesis. Orthogonal contrasts were used to compare the effect of forage source (haylage vs. herbage), supplement (BG vs. SB), and the forage $\times$ supplement interaction. Apparent and true DM and organic matter digestibilities as well as apparent crude protein digestibility were not affected by forage source. However, true DM digestibility was greatest for diets supplemented with SB. Apparent neutral and acid detergent fiber digestibilities of herbage-based diets were higher than haylage-based diets but fiber digestibility was not affected by supplement. Diets supplemented with $\mathrm{SB}$ had higher mean and minimum $\mathrm{pH}$ than $\mathrm{BG}$; however, maximum $\mathrm{pH}$ was not affected by diet. Supple-
\end{abstract}

Received June 24, 2014.

Accepted August 17, 2014.

${ }^{1}$ USDA is an equal opportunity provider and employer.

${ }^{2}$ Corresponding author: Kathy.Soder@ars.usda.gov mentation with $\mathrm{BG}$ produced a greater concentration of total VFA compared with diets supplemented with SB. Haylage-based diets produced greater $\mathrm{CH}_{4}$ output compared with herbage-based diets but supplementation did not affect $\mathrm{CH}_{4}$ output. Efficiency of bacterial protein synthesis was greater for herbage-based diets compared with haylage-based diets, with no effect of supplementation. Overall, supplementation with SB marginally increased true DM digestibility of herbageand haylage-based diets but did not affect fiber and crude protein digestibilities, $\mathrm{CH}_{4}$ output, and bacterial efficiency, compared with BG.

Key words: continuous culture fermentation, grazing, sprouted barley

\section{INTRODUCTION}

Sprouted grain has been suggested as a method to produce fresh forage in areas where water shortages and seasonality of forages are common challenges for livestock producers (Rodríguez-Muela et al., 2005; Rodríguez, 2012). Sprouted barley (SB) is barley grain (BG) that has been soaked in water, placed in trays, and allowed to germinate and sprout for 6 to $8 \mathrm{~d}$ (Peer and Leeson, 1985; Dung et al., 2010a,b; Fazaeli et al., 2012). The resulting interwoven mat of roots and green shoots are then fed to livestock. Sprouting barley seed produces a significant increase in fresh weight during the sprouting duration, as germination converts starch, protein, and lipids to their basic forms (e.g., starch changes to sugar; Chung et al., 1989; Dung et al., 2010a,b; Fazaeli et al., 2012). Barley grain can be produced in many regions of the United States and the price of this small grain has remained relatively affordable $(\$ 0.26 / \mathrm{kg}$ in 2011 ; USDA-ERS, 2011). Barley has been found to produce greater fresh and DM yields when sprouted hydroponically compared with other cereal grains such as wheat (Al-Karaki and Al-Hashimi, 2012). Feeding sprouted grains is an old technology that is gaining renewed interest, particularly in parts of the country such as the Northeast, where producing high-quality forage has recently become more challeng- 
ing due to changing weather patterns (drought or highintensity rainfall events) and a decline in availability of arable land (Nickerson et al., 2011; Griffin et al., 2014). Furthermore, increasing costs of corn, a desire for some grazing dairies to move away from grain supplements, and an interest in an alternative solution to producing high-quality fresh forage year-round have been cited as reasons for dairy farmers to consider using sprouting technology. Finally, manufacturers marketing various sizes of hydroponic livestock feed growth systems have helped lead the reemergence in producer interest with trade-show appearances and internet videos claiming exceptional forage yields and increased animal health and performance. Producer testimonials featured in industry publications have cited anecdotal observations of improved animal health (lower SCC and improved reproductive success, immune response, and milk yield and quality; Anderson, 2009; Sergeant, 2012). However, little scientific evidence is currently available to support claims made by manufacturers of hydroponic livestock feed systems and to justify farmers' adoption of sprouting technology.

Previous research regarding the feeding value of SB and other sprouted grains to ruminants indicates that the benefits of sprouting may be negated by the total DM loss from sprouting coupled with no significant improvement in nutrient concentrations or digestibility (Dung et al., 2010a). Several studies have suggested that feeding sprouted grains may only increase performance in animals not receiving adequate protein, energy, or minerals (Thomas and Reddy, 1962; Sneath and McIntosh, 2003), or that the readily available nutrients in SB may stimulate enhanced utilization of poor-quality forages (Tudor et al., 2003). Currently, no information is available regarding the feeding value of SB with high-quality forages, such as the conserved forages and pastures found on well-managed grazing dairy farms. Therefore, the objective of this study was to use in vitro continuous-culture fermentation to evaluate the effects of supplementing SB or BG with an herbagebased or conserved forage diet on ruminal fermentation, nutrient digestibility, bacterial protein synthesis, and $\mathrm{CH}_{4}$ output. We hypothesized that supplementing herbage- and haylage-based diets with SB will increase nutrient digestibility of these diets and reduce $\mathrm{CH}_{4}$ output compared with BG in continuous culture.

\section{MATERIALS AND METHODS}

\section{Site, Experimental Design, and Diets}

This study was conducted at the USDA-Agricultural Research Service Pasture Systems and Watershed Management Research Unit (University Park, PA) from
January to March 2013. Forages were harvested from a mixed-species pasture containing perennial ryegrass (Lolium perenne L.), Kentucky bluegrass (Poa pratensis L.), white clover (Trifolium repens L.), and red clover (Trifolium pretense L.) in Shippensburg (Pennsylvania) and a tall fescue (Festuca arundinacea) pasture in Kinzers (Pennsylvania) on October 4 and 5, 2012, respectively. At the time of harvest, all forage was at the vegetative stage of development and was composited at a ratio of 2:1 DM for the clover/grass mixture and tall fescue, respectively, to represent typical cool-season grass/legume pastures found on grazing dairy farms in Pennsylvania. Haylage was obtained from a storage bay from a dairy farm in Kinzers and comprised an alfalfa (Medicago sativa L.) and tall fescue mix. Herbage and haylage were stored in freezers at $-20^{\circ} \mathrm{C}$ until freezedrying (Ultra 35 Super ES; VirTis Co. Inc., Gardiner, NY).

The barley (Hordeum vulgare L.) seed used for the BG supplement and to grow the SB was a winter hulless variety purchased from Lakeview Organic Grain LLC (Penn Yan, NY). Clean BG seeds (130 g as fed) were soaked for $6 \mathrm{~h}$ in distilled water and spread in sprouting containers $(8 \times 14 \mathrm{~cm})$ to obtain a depth of $1.9 \mathrm{~cm}$. Sprouted barley was grown for $7 \mathrm{~d}$ in a growth chamber (model no. PGR16; Conviron, Winnipeg, MB, Canada; $81 \times 183 \times 107 \mathrm{~cm}$ ) equipped with automatic sprayer irrigation. The automatic watering system was controlled by an in-line commercial timing device (Orbit model no. 27729; Orbit Irrigation Products Inc., Bountiful, UT) set to deliver water through a fine misting nozzle for 1 min every $6 \mathrm{~h}$. Total water delivered per watering was $1.9 \mathrm{~L}$ and came from the domestic cold water supply and contained $<0.5 \mathrm{mg} / \mathrm{L}$ residual $\mathrm{Cl}$. Holes drilled in the bottom of the sprouting containers allowed for drainage between watering. The temperature inside the chamber was controlled at $21^{\circ} \mathrm{C}$ with $50 \%$ relative humidity. Light from incandescent, metal halide, and sodium light sources provided $12 \mathrm{~h}$ of daily light (0400 to $1600 \mathrm{~h}$ ). To ensure a constant supply of fresh 7-d SB, new containers were seeded daily. Freeze-dried herbage and haylage, as well as the BG were ground to pass through a 2-mm screen (Wiley mill; Thomson Scientific Inc., Philadelphia, PA) to be used as feed for the fermentors.

A separate set of 6 trays of SB were grown simultaneously using the same protocol to determine fresh weight gain and DM loss with each day of sprouting. Each day, 1 tray was removed from the growth chamber and the contents emptied onto a tray with a paper towel and allowed to drain excess water for $30 \mathrm{~min}$. The sprouted seeds were then weighed to determine fresh weight and placed in a forced-air oven for $48 \mathrm{~h}$ at $60^{\circ} \mathrm{C}$ to determine DM content. 
Table 1. Chemical composition (\% of DM, unless otherwise noted) of diet ingredients and haylage- or herbage-based diets supplemented with barley grain (BG) or sprouted barley (SB) during continuous-culture fermentation

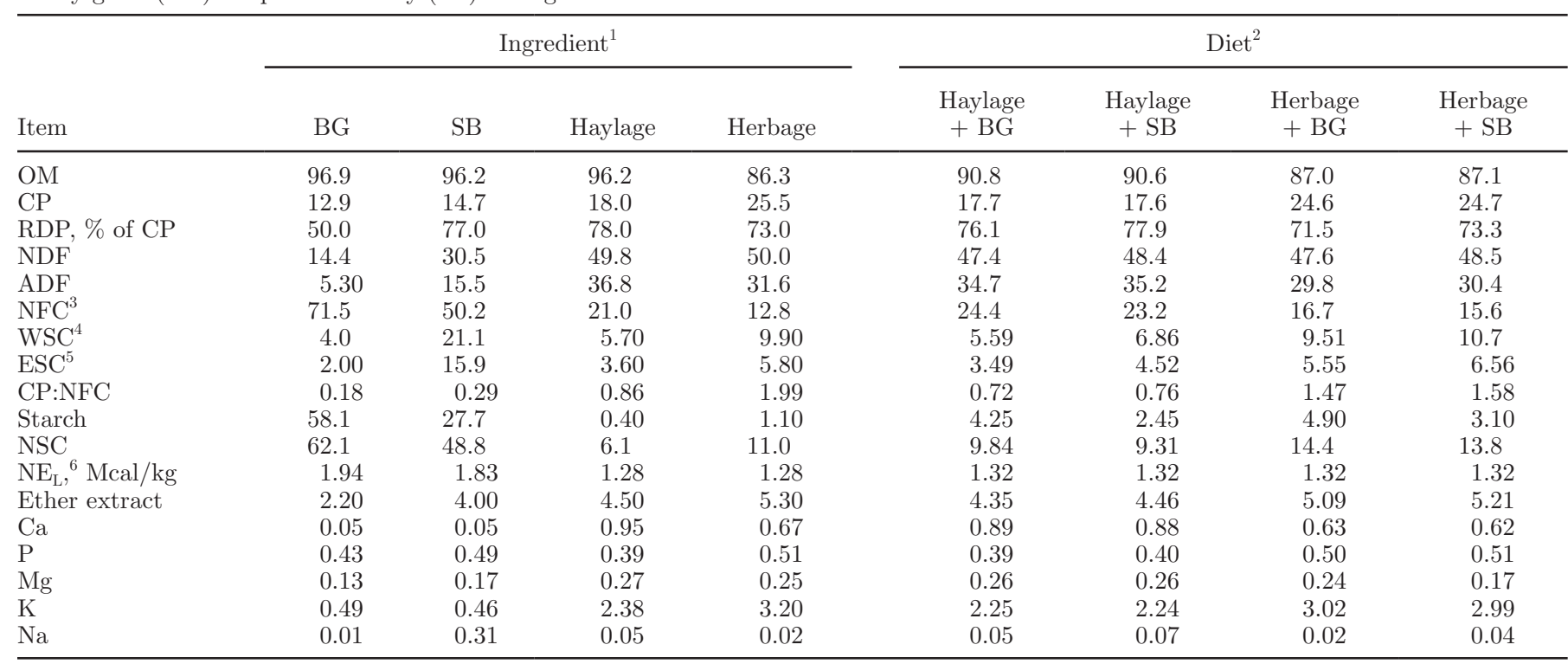

${ }^{1}$ Nutrient composition of diet ingredients from wet chemical analysis (Dairy One Laboratories, Ithaca, NY).

${ }^{2}$ Calculated using actual nutrient composition and proportion of individual ingredients.

${ }^{3} \mathrm{NFC}=\mathrm{CP}(\%)+[\mathrm{NDF}(\%)-$ neutral detergent-insoluble CP $(\%)]+[$ ether extract $(\%)+$ ash $(\%)]$.

${ }^{4}$ Water-soluble carbohydrate.

${ }^{5}$ Ethanol-soluble carbohydrate.

${ }^{6}$ Estimated using the NRC (2001) model.

Total DM (herbage plus supplement) fed to all fermentors was maintained at a constant $60 \mathrm{~g}$ of $\mathrm{DM} / \mathrm{d}$ for the duration of each period. Diets were formulated to be isocaloric using nutrient analysis of dietary ingredients obtained from chemical analysis conducted at a commercial laboratory (Dairy One Laboratories, Ithaca, NY; Table 1) before the start of the study and were as follows: (1) $55.5 \mathrm{~g}$ of herbage $\mathrm{DM}+4.5 \mathrm{~g}$ of SB DM, (2) $56.0 \mathrm{~g}$ of herbage DM $+4.0 \mathrm{~g}$ of BG DM, (3) $55.5 \mathrm{~g}$ of haylage DM $+4.5 \mathrm{~g}$ of SB DM, and (4) $56.0 \mathrm{~g}$ of haylage DM $+4.0 \mathrm{~g}$ of BG DM. Freeze-dried herbage was fed in equal portions daily $(0730,1030$, 1400, and $1900 \mathrm{~h}$ ) and fresh SB and BG were fed twice daily $(0730$ and $1400 \mathrm{~h})$ in equal portions to simulate typical supplementation practices used on dairy farms. At each feeding, the fresh SB was ground in a coffee grinder for $10 \mathrm{~s}$ to facilitate feeding and utilization by the fermentors. At each $0730 \mathrm{~h}$ feeding, a 25-g (as-fed) subsample of SB was taken and stored in a freezer at $-20^{\circ} \mathrm{C}$. All subsamples were composited, freeze-dried, and stored for subsequent nutrient analysis. A representative sample of freeze-dried herbage, haylage, and BG was also stored for later nutrient analysis.

\section{Continuous-Culture Operation}

This study was conducted as a $4 \times 4$ Latin square design with each fermentation unit receiving each dietary treatment once over the 4 periods. Diets were incubated in a 4-unit, dual-flow, continuous-culture fermentor system (Omni-Culture Plus; VirTis Co. Inc.), similar to that described by Hoover et al. (1989), with the following modifications: $\mathrm{pH}$ was not controlled, diets were not pelleted, fermentor volumes ranged from 1,100 to 1,140 $\mathrm{mL}$, and urea was added to the mineral buffer solution at a rate of $0.4 \mathrm{~g} / \mathrm{L}$ to simulate recycled $\mathrm{N}$ (Weller and Pilgrim, 1974). Solid mean retention time, solid dilution rate, and liquid dilution rate of the fermentors were $24 \mathrm{~h}, 4.86 \% / \mathrm{h}$, and $6.93 \% / \mathrm{h}$, respectively, and were achieved by regulation of buffer input and filtrate removal (Bargo et al., 2003a).

Ruminal fluid and digesta samples were collected from a ruminally cannulated, nonlactating, multiparous Holstein cow $(\mathrm{BW}=795 \mathrm{~kg})$ cared for in accordance with the Pennsylvania State University Animal Care and Use (IACUC no. 39513) guidelines. The cow was maintained on a diet of mixed grain and grass hay (65:35 forage:concentrate ratio, ad libitum) and was housed in a covered pen at the Pennsylvania State University dairy farm (University Park). Approximately 3 $\mathrm{h}$ after feeding, $6 \mathrm{~L}$ of ruminal fluid was collected with a hand pump into a prewarmed insulated container. Solid digesta was collected by hand from the ventral, central, and dorsal areas of the rumen. Liquid and whole digesta samples were transported to the USDA-Agricultural 
Research Service laboratory in separate containers. Within 15 min of collection, fluid was strained through 4 layers of cheesecloth and poured into each of the prewarmed fermentation jars until it cleared the overflow spout. Solid digesta was mixed by hand and $25 \mathrm{~g}$ was added to each fermentor. Each fermentor (Alicat Scientific Inc., Tucson, AZ) was continuously purged with $\mathrm{CO}_{2}$ gas at a rate of $20 \mathrm{~mL} / \mathrm{min}$ to maintain anaerobiosis and the temperature was maintained at $39^{\circ} \mathrm{C}$. Fermentor contents were continually stirred at the rate of $255 \mathrm{rpm}$. Fermentor $\mathrm{pH}$ was recorded immediately before each of the 4 daily feedings.

Fermentors were operated for 4 consecutive $10-\mathrm{d}$ periods. Each experimental period consisted of a $7-d$ diet adaptation period followed by a 3 -d sampling period. Liquid and solid overflow were collected in 4-L plastic containers. During the 7-d adaptation period, the overflow containers were weighed daily and the contents discarded. After being emptied on $\mathrm{d} 7$ and continuing through d 10, the containers were immersed in a chilled $\left(4^{\circ} \mathrm{C}\right)$ water bath and each received $20 \mathrm{~mL}$ of $50 \% \mathrm{H}_{2} \mathrm{SO}_{4}$ daily (after being emptied) to inhibit microbial fermentation. During the last $3 \mathrm{~d}$ of each period, liquid and solid overflow from each fermentor were combined and mixed in a blender (Waring Products, New Hartford, CT) for $30 \mathrm{~s}$. After mixing, a $100-\mathrm{mL}$ sample was taken and composited over the $3 \mathrm{~d}$ to determine overflow DM content. For determination of VFA (via gas chromatography; Rumen Fermentation Profiling Laboratory, West Virginia University, Morgantown) and $\mathrm{NH}_{3}-\mathrm{N}$ (Yang and Varga, 1989), a 50-mL sample was strained through 8 layers of cheesecloth before a $15-\mathrm{mL}$ sample was placed in a $30-\mathrm{mL}$ plastic bottle. An additional 1,000-mL sample was composited over the 3-d sample period, freeze-dried, ground to pass through a 1-mm sieve, and stored in a sealed plastic bag for later analyses of DM, OM, NDF, CP, and total purine content. On d 10, in addition to the previously discussed sampling, the contents of each fermentor jar were processed according to the methods of Griswold et al. (1996), with the following modification: in lieu of the initial centrifugation, contents were mixed gently in the blender for $30 \mathrm{~s}$ and strained through 2 layers of $53-\mu \mathrm{m}$ Nitex fabric (Wildco, Buffalo, NY) into a 2-L plastic container with $5 \mathrm{~mL}$ of $50 \% \mathrm{H}_{2} \mathrm{SO}_{4}$ added to retard microbial growth. Contents were then centrifuged 3 times at $20,000 \times g$ for $20 \mathrm{~min}$ at $-4^{\circ} \mathrm{C}$, with the pellet resuspended in $0.9 \%$ saline and $50 \%$ methanol, respectively, for the last 2 centrifugations (Griswold et al., 1996). The final pellet was placed in a plastic container and stored in the freezer until subsequent lyophilization and purine analysis.

\section{$\mathrm{CH}_{4}$ Measurements}

Gas samples for $\mathrm{CH}_{4}$ analysis were collected 6 times daily in duplicate $(0725,0900,1000,1355,1530$, and $1630 \mathrm{~h})$ using a 25 -gauge needle attached to a $30-\mathrm{mL}$ syringe (Vibart et al., 2007). A separate needle and syringe were designated for each fermentor. After the syringe was plunged 3 times to purge any residual gas, the needle was inserted through a rubber septum (part no. 608010; Sigma-Aldrich, St. Louis, MO) located in a port on top of the fermentor, and $30 \mathrm{~mL}$ of gas was withdrawn from the headspace. A stopcock attached between the needle and syringe ensured that gas did not escape upon transference to an evacuated $15-\mathrm{mL}$ glass vial through a septum in the cap. Gas samples were analyzed for $\mathrm{CH}_{4}$ using gas chromatography (Varian CP 3800; Agilent Technologies Inc., Santa Clara, CA) as described in Soder et al. (2012). Daily $\mathrm{CH}_{4}$ output ( $\mathrm{mmol} / \mathrm{d})$ was estimated using the following equation: $\mathrm{CH}_{4}$ concentration in fermentor headspace $(\mathrm{mmol} / \mathrm{mL})$ $\times \mathrm{CO}_{2}$ gas flow through the fermentor headspace $(20$ $\mathrm{mL} / \mathrm{min}) \times 60 \mathrm{~min} \times 24 \mathrm{~h}($ AOAC International, 2006, as cited by Johnson et al., 2009).

\section{Nutrient Analyses}

Samples of herbage, haylage, BG, and SB were analyzed by wet chemistry (Dairy One Laboratories) for the following: DM (method 930.15; AOAC International, 2006), CP (method 990.03; AOAC International, 2006), RDP (Cornell Streptomyces griseus enzymatic digestion; Coblentz et al., 1999), NDF [Ankom Technology method 6 (NDF in Feeds-Filter Bag Technique for A200; Ankom Technology, Fairport, NY); solutions as in Van Soest et al. (1991)], water-soluble carbohydrates (WSC) and ethanol-soluble carbohydrates (Hall et al., 1999), starch (Application Note Number 319; YSI Inc. Life Sciences, Yellow Springs, OH), minerals (Ca, P, Mg, K, and Na; Thermo IRIS Advantage HX or intrepid inductively coupled plasma radial spectrometer after microwave digestion; CEM Application Note for Acid Digestion; CEM, Matthews, NC), and ether extract (EE; method 2003.05; AOAC International, 2006). The NFC concentration was calculated using the equation NFC $(\%)=100 \%-\{\mathrm{CP}(\%)+[\mathrm{NDF}(\%)-$ NDICP (\%)] + EE (\%) + ash (\%)\}. Effluent samples were analyzed for DM and OM (methods 930.15 and 942.05, respectively; AOAC International, 2006) and $\mathrm{CP}$ contents (micro-Kjeldahl digestion using $75-\mathrm{mL}$ calibrated tubes with $\mathrm{CuSO}_{4} / \mathrm{K}_{2} \mathrm{SO}_{4}$ catalyst; method 976.06; AOAC International, 2006). The NDF content of the effluent was determined by the methods of Van 
Soest et al. (1991) with amylase and sodium sulfite used in the NDF procedure (inclusive of ash). Concentrations of total purines (Zinn and Owens, 1986) in effluent and microbial isolates were used to partition effluent $\mathrm{N}$ flow into bacterial and nonbacterial fractions and to calculate true DM and OM digestibilities and flows.

\section{Statistical Analysis and Calculations}

Data were analyzed as a $4 \times 4$ Latin square design with a $2 \times 2$ factorial arrangement of treatments using PROC MIXED of SAS (SAS Institute Inc., Cary, NC) fitted to the following model: $Y_{i j k}=\mu+P_{i}+F_{j}$ $+T_{k}+e_{i j k}$, where $Y_{i j k}=$ observations for dependent variables, $\mu=$ population mean, $P_{i}=$ mean effect of the $i$ th period, $F_{j}=$ mean effect of the $j$ th fermentor, $T_{k}=$ mean effect of the $k$ th treatment, and $e_{i j k}=$ residual error. Preplanned orthogonal contrasts were used to test the main effect of forage source (haylage vs. herbage diets), barley source (BG vs. SB diets), and the forage $\times$ barley source interaction. Period and diet were fixed effects and fermentor and error were random.

Measures of $\mathrm{CH}_{4}$ concentrations were analyzed for temporal patterns using the following model: $Y_{i j k l}=\mu$ $+P_{i}+F_{j}+T_{k}+E_{i j k}+H_{l}+H T_{k l+} e_{i j k}$. Where, $Y_{i j k l}=$ observations for dependent variables, $\mu=$ population mean, $P_{i}=$ mean effect of the $i$ th period, $F_{j}=$ mean effect of the $j$ th fermentor, $T_{k}=$ mean effect of the $k$ th treatment, $E_{i k j}=$ whole-plot error, $H_{l}=$ mean effect of the lth hour samples analyzed as repeated measures, $H T_{k l}=$ interaction between the lth hour and $k$ th treatment, and $\mathrm{e}_{i j k}=$ subplot residual error. All terms were considered as fixed effects, except fermentor, whole-plot error, and subplot error, which were considered as random. An autoregressive covariance structure with the lowest Akaike information criterion values was retained in the final model.

All reported values are least squares means. Significance was declared at $P \leq 0.05$ and trends at $0.05<P$ $\leq 0.10$ for all analyses.

Apparent (DM, OM, CP, NDF, and ADF) and true (DM, OM) digestibilities of nutrients were calculated as follows (DM as an example):

DM apparently digested $(\%$ of total DM $)=$ $[(\mathrm{g}$ of DMI $-\mathrm{g}$ of effluent flow DM $) / \mathrm{g}$ of DMI $] \times 100$, with effluent corrected for grams of buffer DM;

DM truly digested (\% of total DM $)=\{[$ g of DMI (g effluent flow DM - g of bacterial DM)]/g of DMI\} $\times 100$, with effluent corrected for grams of buffer DM.
Nitrogenous fractions flows $(\mathrm{mg} / \mathrm{d})$ were calculated as follows:

$$
\begin{gathered}
\mathrm{NH}_{3}-\mathbf{N} \text { flow }=\left[\left(\text { effluent } \mathrm{NH}_{3}-\mathrm{N}(\mathrm{mg} / 100 \mathrm{~mL})\right.\right. \\
\times(\mathrm{mg} \text { of total effluent flow } / 100)] ;
\end{gathered}
$$

Non- $\mathrm{NH}_{3}-\mathrm{N}$ flow $=(\mathrm{mg}$ of total effluent flow $)$

- (mg of effluent $\left.\mathrm{NH}_{3}-\mathrm{N}\right)$;

Bacterial $\mathrm{N}$ flow $=(\mathrm{mg}$ of microbial DM $)$

$\times(\% \mathrm{~N}$ in microbes $/ 100) ;$

Dietary $\mathrm{N}$ flow $=\left(\mathrm{mg}\right.$ of effluent non- $\left.\mathrm{NH}_{3}-\mathrm{N}\right)$

- (mg of effluent bacterial $\mathrm{N})$;

$\mathrm{RDP}-\mathrm{N}=(\mathrm{mg}$ of total $\mathrm{N}$ intake $)$

- (mg of dietary $\mathrm{N}$ flow).

\section{RESULTS}

\section{Diet Composition and Nutrient Digestibility}

Chemical composition of dietary ingredients and diets are presented in Table 1. No forage (haylage or herbage) by supplement (SB or BG) interactions were observed for apparent and true nutrient digestibilities (Table 2). Apparent and true DM digestibilities were not affected by forage source. Apparent NDF and ADF digestibilities were 6.7 and 3.4 percentage units greater $(P \leq 0.05)$, respectively, for the herbage-based diets compared with the haylage-based diets but these 2 variables were not affected by supplement type. Apparent DM digestibility tended $(P=0.07)$ to be greater for diets supplemented with SB compared with those supplemented with BG (62.5 vs. $59.5 \%$, respectively). However supplement type had no effect on apparent $\mathrm{OM}$ digestibility. True DM and $\mathrm{OM}$ digestibilities demonstrated the same pattern, such that true DM digestibility was 3 percentage units greater $(P=0.05)$ for diets supplemented with SB compared with diets supplemented with BG, whereas OM digestibility was not affected by supplement type.

\section{Fermentor $\mathrm{pH}, \mathrm{VFA}$, and $\mathrm{CH}_{4}$ Output}

No forage $\times$ supplement interactions were observed for mean, minimum, and maximum fermentor $\mathrm{pH}$ (Table 3). Mean fermentor $\mathrm{pH}$ was not affected by forage source (averaging 6.71). However, diets supplemented 
Table 2. Nutrient digestibility (\%) of haylage- and herbage-based diets supplemented with barley grain (BG) or sprouted barley (SB) during continuous-culture fermentation

\begin{tabular}{|c|c|c|c|c|c|c|c|c|}
\hline \multirow[b]{2}{*}{ Item } & \multicolumn{4}{|c|}{ Diet } & \multirow[b]{2}{*}{ SEM } & \multicolumn{3}{|c|}{ Contrast, $P$-value } \\
\hline & $\begin{array}{c}\text { Haylage } \\
+ \text { BG }\end{array}$ & $\begin{array}{c}\text { Haylage } \\
+ \text { SB }\end{array}$ & $\begin{array}{c}\text { Herbage } \\
+\mathrm{BG}\end{array}$ & $\begin{array}{l}\text { Herbage } \\
+ \text { SB }\end{array}$ & & $\begin{array}{c}\text { Haylage } \\
\text { vs. herbage }\end{array}$ & $\begin{array}{l}\text { BG vs. } \\
\text { SB }\end{array}$ & $\begin{array}{c}\text { Forage } \times \\
\text { supplement }\end{array}$ \\
\hline \multicolumn{9}{|c|}{ Apparent digestibility } \\
\hline DM & 60.1 & 62.8 & 58.8 & 62.2 & 1.33 & 0.51 & 0.07 & 0.81 \\
\hline OM & 67.9 & 69.7 & 66.9 & 68.4 & 1.37 & 0.28 & 0.13 & 0.89 \\
\hline NDF & 72.3 & 71.8 & 78.8 & 78.8 & 1.35 & 0.001 & 0.84 & 0.84 \\
\hline DM & 75.7 & 79.3 & 76.3 & 78.6 & 1.31 & 0.97 & 0.05 & 0.58 \\
\hline OM & 81.4 & 83.8 & 83.4 & 84.0 & 0.94 & 0.24 & 0.13 & 0.32 \\
\hline
\end{tabular}

with SB had greater $(P<0.05)$ mean and minimum $\mathrm{pH}$ than diets supplemented with BG. A tendency $(P=$ 0.09) existed for herbage-based diets to have a greater minimum $\mathrm{pH}$ compared with haylage-based diets. Maximum fermentor $\mathrm{pH}$ was similar among diets and averaged 6.75 .

No forage $\times$ supplement interaction was observed for total VFA concentration (Table 3). Total VFA concentration was affected by both forage and supplement type, such that haylage-based diets produced a greater $(P<0.01)$ concentration of total VFA compared with herbage-based diets, whereas diets supplemented with BG produced a greater $(P=0.03)$ concentration of total VFA compared with diets supplemented with SB. Forage $\times$ supplement interactions were observed for molar proportions of propionate $(P=0.04)$ and acetate:propionate $(\mathbf{A}: \mathbf{P})$ ratio $(P=0.02)$; the molar proportion of propionate was greater $(P<0.01)$ for haylage-based diets compared with herbage-based diets, but it did not differ between supplement types. Molar proportions of acetate were affected by both forage and supplement type. Molar proportions of acetate, butyrate, and valerate were greater $(P<0.05)$ for haylage-based diets compared with herbage-based diets, and greater $(P<0.05)$ for diets supplemented with BG compared with those supplemented with SB. Molar proportions of isobutyrate and isovalerate were not affected by diet.

No forage $\times$ supplement interaction was observed for $\mathrm{CH}_{4}$ output (Table 3). Haylage-based diets had greater outputs of $(P=0.006)$ of daily $\mathrm{CH}_{4}$ and greater $(P$ $<0.05) \mathrm{CH}_{4}$ output when expressed as milligrams per gram of OM intake, NDF intake, and digestible NDF. Supplementation of BG and SB did not affect daily $\mathrm{CH}_{4}$ output, or $\mathrm{CH}_{4}$ output expressed as milligrams per gram of OM intake, NDF intake, and digestible NDF.

Table 3. Fermentor pH, VFA profiles, and $\mathrm{CH}_{4}$ output of haylage- and herbage-based diets supplemented with barley grain (BG) or sprouted barley (SB) during continuous-culture fermentation

\begin{tabular}{|c|c|c|c|c|c|c|c|c|}
\hline Item & \multicolumn{4}{|c|}{ Diet } & SEM & \multicolumn{3}{|c|}{ Contrast, $P$-value } \\
\hline Mean & 6.67 & 6.71 & 6.70 & 6.75 & 0.02 & 0.14 & 0.05 & 0.87 \\
\hline Minimum & 6.64 & 6.68 & 6.68 & 6.71 & 0.01 & 0.09 & 0.04 & 0.68 \\
\hline Maximum & 6.71 & 6.75 & 6.73 & 6.80 & 0.03 & 0.31 & 0.15 & 0.64 \\
\hline Acetate (A), mol/100 mol & 46.9 & 42.6 & 43.0 & 40.5 & 1.65 & 0.04 & 0.02 & 0.44 \\
\hline Propionate $(\mathrm{P}), \mathrm{mol} / 100 \mathrm{~mol}$ & 18.6 & 17.2 & 11.2 & 11.8 & 0.50 & $<0.001$ & 0.38 & 0.04 \\
\hline Butyrate, mol/100 mol & 6.59 & 5.82 & 5.40 & 5.15 & 0.25 & 0.001 & 0.02 & 0.16 \\
\hline Isobutyrate, $\mathrm{mol} / 100 \mathrm{~mol}$ & 0.57 & 0.51 & 0.53 & 0.53 & 0.03 & 0.70 & 0.25 & 0.28 \\
\hline Valerate, mol/100 mol & 1.82 & 1.61 & 1.38 & 1.22 & 0.07 & $<0.001$ & 0.03 & 0.72 \\
\hline Isovalerate, $\mathrm{mol} / 100 \mathrm{~mol}$ & 0.40 & 0.39 & 0.43 & 0.40 & 0.03 & 0.24 & 0.22 & 0.36 \\
\hline $\mathrm{A}: \mathrm{P}$ & 2.52 & 2.48 & 2.86 & 2.45 & 0.06 & $<0.001$ & 0.01 & 0.02 \\
\hline
\end{tabular}




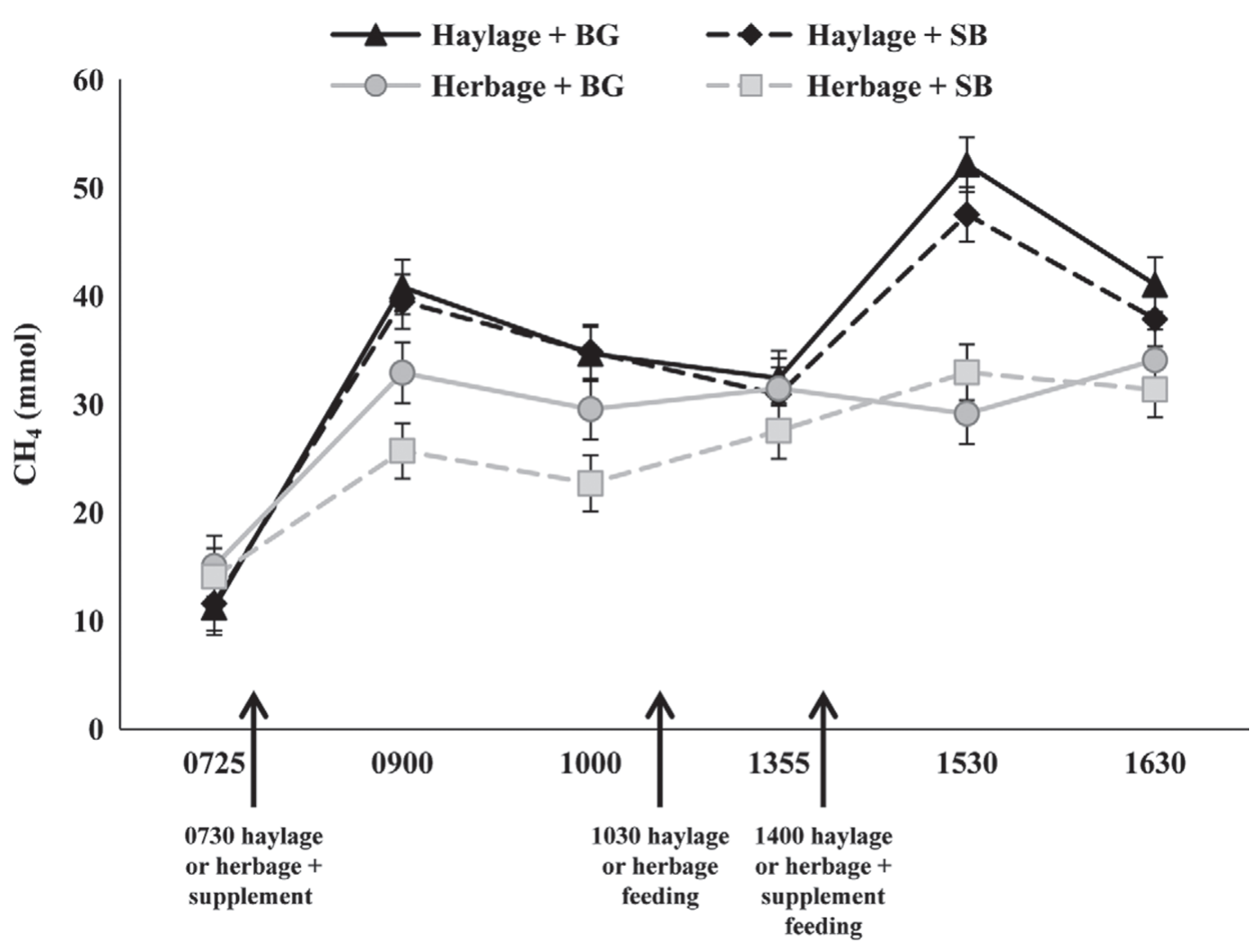

Times of $\mathrm{CH}_{4}$ sampling and feeding

Figure 1. Temporal $\mathrm{CH}_{4}$ output of haylage- and herbage-based diets supplemented with barley grain (BG) or sprouted barley (SB) during continuous-culture fermentation. The final feeding of the day occurred at $1900 \mathrm{~h}$; however, it is not depicted on this figure, as no $\mathrm{CH}_{4}$ samples were taken past $1630 \mathrm{~h}$. Error bars represent SE.

Temporal patterns indicated a significant $(P<0.001)$ diet $\times$ sampling time interaction for daily $\mathrm{CH}_{4}$ output (Figure 1). Methane output was the lowest for all treatments when sampled immediately before the 0730 $\mathrm{h}$ feeding of herbage and supplement, and increased markedly after feeding. After the $1400 \mathrm{~h}$ haylage or herbage and supplement feeding, haylage-based diets produced an increased amount of $\mathrm{CH}_{4}$, compared with the herbage-based diets, which remained less variable throughout the day.

\section{Nitrogen Metabolism}

Forage $\times$ supplement interactions were observed for $\mathrm{NH}_{3}-\mathrm{N}$ concentration $(P=0.01), \mathrm{CP}$ digestibility $(P$ $=0.01), \mathrm{NH}_{3}-\mathrm{N}$ flow $(P=0.01)$, non- $\mathrm{NH}_{3}$-flow $(P=$ $0.006)$, and dietary $\mathrm{N}$ flow $(P=0.01$; Table 4$)$. Dietary $\mathrm{N}$ flow tended $(P=0.08)$ to be greater for the herbagebased diets compared with haylage-based diets; however, this variable was not affected by supplement type. Total $\mathrm{N}$ flow was greater $(P<0.001)$ for the herbagebased diets compared with the haylage-based diets and tended $(P=0.07)$ to be greater for diets supplemented with BG compared with those supplemented with SB. Ammonia- $\mathrm{N}$ concentration and $\mathrm{NH}_{3}-\mathrm{N}$ flows tended $(P$ $=0.07$ and $P=0.06$, respectively) to be greater for the herbage-based diets compared with the haylage-based diets, whereas no differences existed between supplement types. The $\mathrm{NH}_{3}-\mathrm{N}$ concentration and $\mathrm{NH}_{3}-\mathrm{N}$ flows were numerically greater for the haylage-based diet supplemented with BG and for the herbage-based diet supplemented with SB, thus resulting in the observed interactions. No differences were observed for CP digestibility among diets. Non- $\mathrm{NH}_{3}-\mathrm{N}$ concentration was greater $(P=0.007)$ for the herbage-based diets compared with the haylage-based diets. No significant differences existed for non- $\mathrm{NH}_{3}-\mathrm{N}$ flows between supplement types. However, numeric differences resulting in greater non- $\mathrm{NH}_{3}-\mathrm{N}$ flows in the haylage-based diet supplemented with SB and in the herbage-based diet supplemented with BG resulted in the forage $\times$ supplement interaction. Bacterial $\mathrm{N}$ flows were greater $(P=$ 0.01) in the herbage-based diets compared with the haylage-based counterparts but no effect of supplement type was observed. Bacterial efficiency expressed as grams of bacterial $\mathrm{N}$ per kilogram of DM or OM truly 
Table 4. Nitrogen metabolism of haylage and herbage-based diets supplemented with barley grain (BG) or sprouted barley (SB) during continuous-culture fermentation

\begin{tabular}{|c|c|c|c|c|c|c|c|c|}
\hline \multirow[b]{2}{*}{ Item } & \multicolumn{4}{|c|}{ Diet } & \multirow[b]{2}{*}{ SEM } & \multicolumn{3}{|c|}{ Contrast, $P$-value } \\
\hline & $\begin{array}{c}\text { Haylage } \\
+ \text { BG }\end{array}$ & $\begin{array}{l}\text { Haylage } \\
+ \text { SB }\end{array}$ & $\begin{array}{l}\text { Herbage } \\
+\mathrm{BG}\end{array}$ & $\begin{array}{c}\text { Herbage } \\
+\mathrm{SB}\end{array}$ & & $\begin{array}{c}\text { Haylage } \\
\text { vs. herbage }\end{array}$ & $\begin{array}{l}\text { BG vs. } \\
\text { SB }\end{array}$ & $\begin{array}{c}\text { Forage } \times \\
\text { supplement }\end{array}$ \\
\hline $\mathrm{N}$ intake, $\mathrm{mg} / \mathrm{dL}$ & 2,290 & 2,296 & 2,959 & 2,965 & 9.22 & $<0.001$ & 0.13 & 0.92 \\
\hline $\mathrm{NH}_{3}-\mathrm{N}, \mathrm{mg} / \mathrm{dL}$ & 19.3 & 14.4 & 17.6 & 21.3 & 1.38 & 0.07 & 0.62 & 0.01 \\
\hline $\mathrm{CP}$ digestibility, $\%$ & 95.1 & 84.0 & 84.2 & 91.9 & 2.68 & 0.55 & 0.50 & 0.01 \\
\hline \multicolumn{9}{|l|}{$\mathrm{N}$ flows, $\mathrm{mg} / \mathrm{dL}$} \\
\hline Non- $\mathrm{NH}_{3}-\mathrm{N}$ & 727 & 812 & 1,156 & 927 & 64.2 & 0.006 & 0.31 & 0.05 \\
\hline Bacterial N & 665 & 671 & 782 & 735 & 45.2 & 0.01 & 0.44 & 0.33 \\
\hline Dietary N & 82.3 & 141 & 373 & 191 & 106 & 0.03 & 0.31 & 0.08 \\
\hline RDP-N & 2,206 & 2,155 & 2,586 & 2,773 & 105 & 0.003 & 0.27 & 0.08 \\
\hline \multicolumn{9}{|l|}{ Bacterial efficiency } \\
\hline $\mathrm{g}$ of bacterial $\mathrm{N} / \mathrm{kg}$ of $\mathrm{DM}$ truly digested & 14.5 & 14.1 & 17.1 & 15.6 & 0.80 & 0.04 & 0.23 & 0.49 \\
\hline $\mathrm{g}$ of bacterial $\mathrm{N} / \mathrm{kg}$ of $\mathrm{OM}$ truly digested & 15.7 & 15.4 & 18.5 & 17.6 & 1.38 & 0.02 & 0.49 & 0.68 \\
\hline
\end{tabular}

digested were greater $(P<0.05)$ for the herbage-based diets compared with the haylage-based diets, with no effect of supplement type observed.

\section{DISCUSSION}

\section{Diet Composition and Sprouting Yield}

The use of pooled samples for compositional analysis of diet ingredient samples precluded statistical comparison of diets. Crude protein and NDF values for BG were typical of feed-grade barley (NRC, 2001). Nutrient concentration of the herbage used in this study was considered moderate to good quality, with high CP ( $26 \%$ of $\mathrm{DM}$ ) and moderate NDF concentrations (50\% of DM; Bargo et al., 2003b). The nutrient concentration of the haylage used in this study was within expectation for conserved forage originating from a mostly alfalfa/grass mix (Kung et al., 2010). A numeric increase in CP, NDF, WSC, and EE concentration of 1.8, 16.1, 17.1, and 1.8 percentage units, respectively, was observed in the SB compared with the BG from which it originated. However, a slight $(0.11 \mathrm{Mcal} / \mathrm{kg})$ numeric decrease in $\mathrm{NE}_{\mathrm{L}}$ was observed with sprouting. Previous studies have reported similar changes in nutrient concentrations associated with germination and hydroponic sprouting of BG (Dung et al., 2010a,b; Fazaeli et al., 2012). Fazaeli et al. (2012) reported an increase in CP and NDF of 1.95 and 11.6 percentage units and a decrease in $\mathrm{ME}$ of $0.28 \mathrm{Mcal} / \mathrm{kg}$ of $\mathrm{DM}$, respectively with $7 \mathrm{~d}$ of sprouting. These changes in nutrient concentration are expected, as sprouting of seeds initiates hydrolysis of proteins, carbohydrates, and lipids into their simpler components, thus resulting in increased AA, soluble sugars, and FA concentrations (Chavan and Kadam, 1989). This is further supported by a 30.4-percentage- unit numeric decrease in starch from BG to the 7-d SB observed in the current study.

It is important to note that although fresh weight can increase significantly, DM yield decreases with sprouting (Dung et al., 2010b; Fazaeli et al., 2012). Some studies have reported DM losses ranging from 9.4 to $18 \%$ with sprouting (Peer and Leeson, 1985; Chung et al., 1989) as a result of water uptake and the transformation of dry seed into root mass and seedling. In agreement, the SB grown for the current study demonstrated a DM yield loss of $17 \%$ from the BG used to grow the SB (123 g of DM) to the 7-d sprouts (102 g of DM), whereas fresh weight increased $327 \%$ from the dry BG to 7-d SB (Figure 2). The loss of DM yield with sprouting, coupled with the slight numeric decrease in $\mathrm{NE}_{\mathrm{L}}$, would result in a decrease of net available energy for the animal, as $123 \mathrm{~g}$ of BG DM would contain a total of $0.24 \mathrm{Mcal}$ of $\mathrm{NE}_{\mathrm{L}}$ and the subsequent sprouted mat (102 $\mathrm{g}$ of DM) would contain a total of 0.19 Mcal of $\mathrm{NE}_{\mathrm{L}}$.

Diets were formulated to be isocaloric $\left(\mathrm{NE}_{\mathrm{L}}=1.32\right.$ $\mathrm{Mcal} / \mathrm{kg}$ of DM). Crude protein content was noticeably greater (approximately 25\% of DM) for herbage-based diets compared with the haylage-based diets (approximately $18 \%$ of DM). Additionally, diets supplemented with BG had noticeably greater starch content $(4.25$ and $4.90 \%$ starch for haylage-based and herbage-based diets, respectively) compared with diets supplemented with SB (2.45 and 3.10\% starch for haylage-based and herbage-based diets, respectively).

\section{Nutrient Digestibility}

Apparent $\mathrm{DM}$ and $\mathrm{OM}$ digestibilities ranged from 58.8 to $62.8 \%$ and 66.9 to $69.7 \%$, respectively, across diets (Table 2). These values are in general agreement 
a

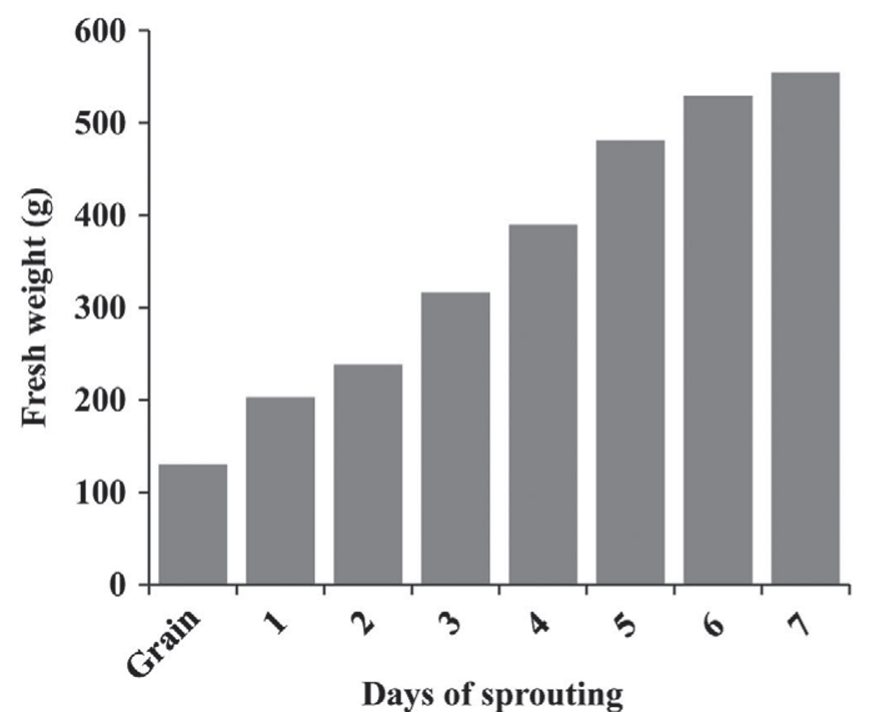

b

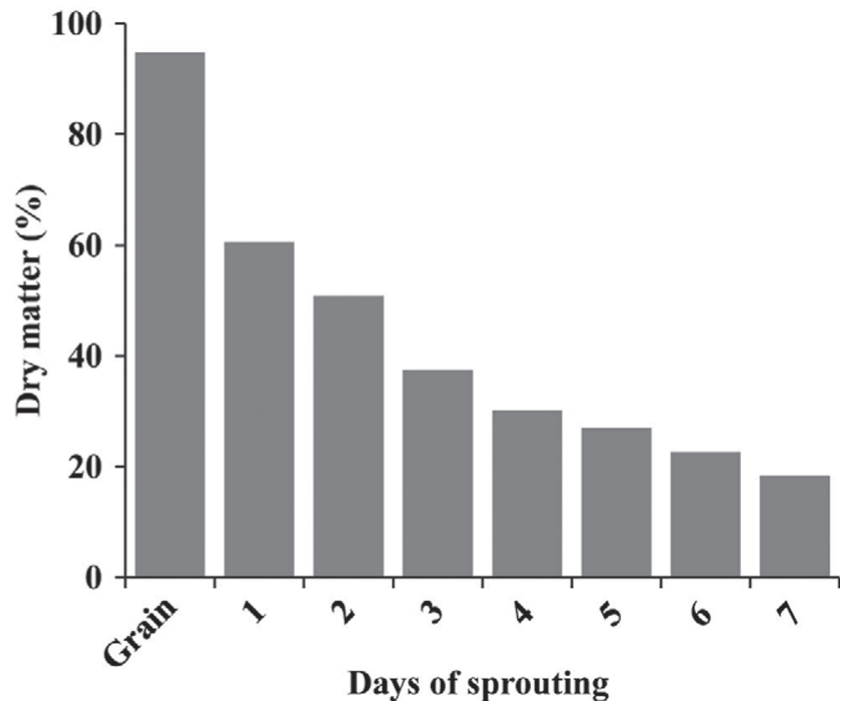

Figure 2. Daily increase in fresh weight of barley during $7 \mathrm{~d}$ of sprouting (a) and percentage DM of barley grain and fresh barley during 7 $\mathrm{d}$ of sprouting (b).

with previously reported values for ryegrass- and orchardgrass-only diets fermented in continuous culture, with apparent DM and OM digestibilities ranging from 49 to $70.2 \%$ and 58 to $72.4 \%$, respectively (de Veth and Kolver, 2001; Bargo et al., 2003a; Soder et al., 2012). Whereas forage source did not affect apparent or true DM and OM digestibilities, apparent NDF and ADF digestibilities were greater for herbage-based diets compared with haylage-based diets (Table 2). The increased digestion of fiber fractions in the herbage-based diets may be explained by a greater concentration of WSC compared with the haylage-based diets (10.1 vs. $6.2 \%$ WSC, for herbage- and haylage-based diets, respectively).

Supplementation of SB increased apparent $(P=$ $0.07)$ and true $(P=0.05)$ DM digestibilities of herbage- and haylage-based diets by 3 percentage units compared with supplementation of BG. Several previous studies have examined the nutrient digestibility of sprouted grains and the use of SB as a supplement, but have reported conflicting results. For instance, Fazaeli et al. (2012) incubated SB in vitro with ruminal fluid within glass syringes and reported a decrease in true OM digestibility with successive days of sprouting (6 to $8 \mathrm{~d}$ ), and OM digestibility was found to be lower at d 8 compared with BG (81.9 vs. $87.6 \%$, respectively). The decrease in digestibility was likely a result of higher fiber fractions and lower NFC observed in the SB compared with the BG. Dung et al. (2010a) used Merino sheep to evaluate the in sacco digestibility of 7-d SB and cracked BG and reported no differences in 96-h DM disappear- ance, although both feeds were highly digestible $(>80 \%$ DM disappearance). Those authors concluded that the $21 \%$ loss in DM production observed during the sprouting process, coupled with no significant improvement in DM digestibility in sacco, would result in a considerable reduction in total digestible energy available for animal production (Dung et al., 2010a). In a follow-up study, Dung et al. (2010b) evaluated the in sacco digestibility of SB in sheep consuming a low-quality forage (oat chaff; $\mathrm{CP}=8.1 \%$ of $\mathrm{DM}$ ). The authors reported no differences in DM or OM digestibility between diets composed of oaten chaff or diets of oaten chaff supplemented with fresh or freeze-dried SB (supplementation rates not reported). Conversely, Fayed (2011) reported significant increases in apparent DM, OM, CP, EE, and cellulose digestibilities when rice straw $(\mathrm{CP}=3.09 \%$ of DM; $\mathrm{NDF}=71.3 \%$ of DM) was supplemented with 10-d SB to lambs. Rice straw was used as a medium to grow the SB for $10 \mathrm{~d}$, and the resulting mat (CP $=11.0 \%$ of $\mathrm{DM} ; \mathrm{NDF}=59.6 \%$ of $\mathrm{DM})$ was fed in a digestion study, using lambs, to compare the digestibility of dry rice straw alone to the rice straw-SB mat. A grain-based supplement $(\mathrm{CP}=11.0 \%$ of $\mathrm{DM})$ was fed at $60 \%$ of maintenance energy requirements with all diets (Fayed, 2011). In all of the aforementioned studies (Dung et al., 2010a,b; Fayed, 2011), DMI was increased with the supplementation of SB. It is possible that the release of soluble carbohydrates and $\mathrm{N}$ from the SB stimulated microbial growth, colonization, and improved degradation of the low-protein forages used in these experiments (Pond et al., 1984), as previous 
studies have reported an increase of DMI of low-quality forages with protein supplementation (Krehbiel et al., 1998; McCollum and Galyean, 1985). However, the haylage and herbage forages comprising the basal diet in the current study had relatively high concentrations of CP (18 and $26 \%$ of DM, respectively) and the modest increase in DM digestibility may instead be due to a greater fraction of WSC in diets supplemented with SB compared with diets supplemented with BG.

Proponents of SB assert that up to $25 \%$ less feed is required to maintain animal productivity, anecdotally claiming much greater nutrient digestibility of the SB. However, this was not substantiated in the current study where OM, NDF, ADF, and CP digestibilities were similar between SB and BG diets, and DM digestibility only showed a tendency to be slightly greater for SB diets (3 percentage units), which would dispute those claims. However, further in vivo animal studies with SB are required to substantiate the results of this continuous-culture fermentation study.

\section{Fermentor $\mathrm{pH}, \mathrm{VFA}$, and $\mathrm{CH}_{4}$ Output}

Herbage-based diets tended to produce a higher minimum fermentor $\mathrm{pH}$ compared with haylage-based diets. Soder et al. (2013) reported greater fermentor $\mathrm{pH}$ for an herbage-based diet composed only of orchardgrass (Dactylis glomerata L.) compared with a $100 \%$ TMR diet (6.62 vs. 6.37, respectively), where the TMR contained $52.4 \%$ of DM as corn silage and $13.4 \%$ of DM as alfalfa haylage. Supplement type affected mean and minimum $\mathrm{pH}$, such that diets supplemented with SB produced greater $\mathrm{pH}$ compared with those supplemented with BG. Fermentor $\mathrm{pH}$ has been found to decrease with increasing starch supplementation of herbage-based diets in continuous culture (Bach et al., 1999; Wales et al., 2009). However, Dung et al. (2010b) reported no differences in rumen $\mathrm{pH}$ of sheep fed oaten chaff supplemented with barley grain or barley sprouts. Proponents of SB suggest that feeding sprouts results in a less acidic ruminal environment compared with grains, which would reduce the occurrence of ruminal acidosis. It is important to note, however, that the increased fermentor $\mathrm{pH}$ with $\mathrm{SB}$ observed was marginal in the present study.

Concentrations of VFA reported in this study are within ranges of those reported in other continuousculture fermentation studies evaluating similar diets and supplements (Bach et al., 1999; Bargo et al., 2003a; Soder et al., 2013). Total VFA concentration and molar proportions of acetate, propionate, butyrate, and valerate were greater in haylage-based diets compared with herbage-based diets. Increased total VFA concentration and molar proportions of propionate and valerate with increasing amounts of NFC have been reported previously in continuous culture (Stokes et al., 1991). The haylage-based diets used in the current study had numerically greater concentrations of NFC compared with the herbage-based diets, which likely contributed to the greater concentration of total VFA and molar proportions of propionate and valerate. The greater proportions of acetate observed in the haylage-based diets was not expected, as ruminal acetate is derived primarily from the fermentation of structural carbohydrates and, in the current study, NDF and ADF digestibilities were greater for the herbage-based diets. However, it is important to note that although NDF concentrations were relatively constant between the haylage-based and herbage-based diets (47.4 and 48.4 vs. 47.6 and $48.5 \%$ of $\mathrm{DM}$, respectively), $\mathrm{ADF}$ values were more divergent (34.7 and 35.2 vs. 29.8 and $30.4 \%$, of DM, respectively), and may have contributed to the greater molar proportions of acetate in the haylage-based diets compared with the herbage-based diets. Soder et al. (2013) reported greater total VFA concentrations, molar proportions of acetate, propionate, isovalerate, and A:P ratio when a $100 \%$ TMR diet (approximately $66 \%$ of DM from silage and haylage) was compared with an entirely orchardgrass diet. However, these results were attributed to the noticeably higher starch and WSC concentrations in the TMR diet.

Total VFA concentration, molar proportions of acetate, butyrate, and valerate were greater for diets supplemented with BG compared with diets supplemented with SB. Total VFA concentrations have been demonstrated to increase with starch supplementation (Feng et al., 1995). Diets supplemented with BG had numerically greater starch content compared with diets supplemented with SB (4.25 and 4.90 vs. 2.45 and $3.10 \%$ of DM, respectively), which may have contributed to greater total VFA concentrations in BG-supplemented diets. Dung et al. (2010b) found that total VFA, acetate, propionate, and butyrate were similar in sheep fed oaten chaff supplemented with SB or BG, and those authors determined that the nutritional composition and form of the treatments evaluated would not have differed in fermentation patterns enough to give rise to differences in VFA proportions. Hillier and Perry (1969) fed 6-d sprouted oat grass at increasing levels $(0,0.63,0.95$, and $1.26 \mathrm{~kg}$ of $\mathrm{DM} / \mathrm{d})$ to Hereford steers consuming low- and high-concentrate diets and reported no significant effects in the total VFA concentrations. In addition, a narrowing of the A:P ratio with increasing sprouted oat grass supplementation to the low-concentrate ration was observed (Hillier and Perry, 1969).

Haylage-based diets produced $27 \%$ more $\mathrm{CH}_{4} / \mathrm{d}$ compared with herbage-based diets (Table 3). More- 
over, haylage-based diets produced more $\mathrm{CH}_{4}$ when expressed as milligrams of $\mathrm{CH}_{4}$ per gram of $\mathrm{OM}$ fed, milligrams of $\mathrm{CH}_{4}$ per gram of NDF fed, and milligrams of $\mathrm{CH}_{4}$ per gram of digestible NDF fed compared with herbage-based diets. Relative differences in $\mathrm{CH}_{4}$ output between forage source was likely attributed to differences in fiber digestibility, as herbage-based diets had greater NDF and ADF digestibilities compared with haylage-based diets. Furthermore, haylage-based diets contained higher concentrations of ADF, and slowly digestible fractions of the feed (i.e., structural fiber) are associated with greater $\mathrm{CH}_{4}$ production (Getachew et al., 2005). Greater molar concentration of butyrate in haylage-based diets, compared with herbage-based diets, supports greater $\mathrm{CH}_{4}$ production, as butyrate increases hydrogen available in the rumen, which is utilized by methanogens to produce $\mathrm{CH}_{4}$ (Moss et al., 2000). It is generally accepted that feeding highprotein, low-fiber rations, specifically by feeding more concentrates, can reduce total enteric $\mathrm{CH}_{4}$ production and $\mathrm{CH}_{4}$ production per unit of product (Shibata and Terada, 2010). However, the cultivation of high-quality forages, which may be cheaper than grain feeds and require reduced fossil fuel inputs for tillage of pasture and forage crop (e.g., hay, silage, and haylage) fields, have been suggested as a feasible option to potentially decrease $\mathrm{CH}_{4}$ output by ruminant livestock production (Boadi, et al., 2004). O'Neill et al. (2011) found that spring-calving Holstein-Friesian cows consuming highquality perennial ryegrass pasture produced less total enteric $\mathrm{CH}_{4}$ emissions per cow, per unit of intake, and per unit of milk fat and protein yield compared with their counterparts offered a standard TMR diet. Furthermore, in a similar study, O'Neill et al. (2012) found that lactating dairy cows consuming a partial TMR combined with pasture produced more total enteric $\mathrm{CH}_{4}$, but similar amounts of $\mathrm{CH}_{4}$ per kilogram of milk yield, compared with cows consuming high and low allowances of high-quality permanent perennial ryegrass pasture. O'Neill et al. (2012) attributed the differences in total enteric $\mathrm{CH}_{4}$ production to an increase in DMI by cows consuming pasture and the partial TMR and the corresponding increase in milk production negated any differences in $\mathrm{CH}_{4}$ per kilogram of milk yield between the treatments. Indeed, as feed intake, digestibility, and feed retention are important factors influencing $\mathrm{CH}_{4}$ production, offering high-quality pasture such as the herbage used in this study may be a strategy to mitigate $\mathrm{CH}_{4}$ emissions compared with rations containing conserved forages higher in slowly digestible fractions.

Supplementation type did not affect $\mathrm{CH}_{4}$ output in the current study. Conversely, Fazaeli et al. (2012) reported that in vitro total gas output was greater when BG was fermented compared with 6- to 8-d SB, and attributed the differences to the increased fiber fractions in the SB compared with the BG. In the current study, SB and BG made up only 7.5 and $6.6 \%$ of the total diet DM, respectively, and it is possible that any potential differences in $\mathrm{CH}_{4}$ output between the supplements were negated by the basal diets.

The lowest $\mathrm{CH}_{4}$ output was observed for all treatments when sampled immediately before the $0730 \mathrm{~h}$ feeding of forage and supplement (Figure 1). This observation was likely due to depletion of substrate in the continuous-culture system, as the previous feeding (forage only) occurred $12 \mathrm{~h}$ prior. The haylage-based diets resulted in more temporal variation of $\mathrm{CH}_{4}$ output compared with the herbage diets due to the addition of more slowly digestible fractions at feeding. It is reasonable to consider that the spikes in $\mathrm{CH}_{4}$ output observed for the haylage-based diet may correspond with decreased nutrient digestibility at those same time points. To our knowledge, no previous continuous-culture studies have investigated temporal patterns of $\mathrm{CH}_{4}$ output.

\section{Nitrogen Metabolism}

The tendency for fermentor $\mathrm{NH}_{3}-\mathrm{N}$ to be higher in the herbage-based diets may be explained by enhanced $\mathrm{N}$ input (Table 4). Enhanced $\mathrm{N}$ intake has been associated with increased concentration of ruminal $\mathrm{NH}_{3}-\mathrm{N}$ in lactating dairy cows fed diets with incremental concentrations of CP (Olmos Colmenero and Broderick, 2006a). A significant forage $\times$ supplement interaction was observed, indicating that herbage supplemented with SB and haylage supplemented with BG showed the greatest concentrations of $\mathrm{NH}_{3}-\mathrm{N}$, which may be explained by enhanced CP digestibility. In fact, a significant forage $\times$ supplement interaction was observed for $\mathrm{CP}$ digestibility, with the highest values obtained when fermentors were fed haylage and BG and herbage and SB. Enhanced ruminal digestibility of $\mathrm{CP}$ coincided with increased concentration of ruminal $\mathrm{NH}_{3}-\mathrm{N}$ in dairy cows fed diets ranging from 13.5 to $19.4 \% \mathrm{CP}$ (Olmos Colmenero and Broderick, 2006a,b). Thus, it can be hypothesized that the rate of $\mathrm{NH}_{3}-\mathrm{N}$ release from herbage NPN was faster than that of sugars (i.e., WSC) from $\mathrm{SB}$, resulting in $\mathrm{NH}_{3}-\mathrm{N}$ accumulation. It can be also hypothesized that $\mathrm{NH}_{3}-\mathrm{N}$ resulting from the breakdown of haylage NPN was not released in a timely manner with fermentable energy (i.e., starch) from BG, leading to accumulation of $\mathrm{NH}_{3}-\mathrm{N}$.

Total $\mathrm{N}$ flow was significantly higher in fermentors fed the herbage-based diets compared with those fed the haylage-based counterparts, which can be explained by enhanced $\mathrm{N}$ input and bacterial $\mathrm{N}$ flow in herbageversus haylage-based diets (Table 4). When $\mathrm{N}$ intake increased linearly from 476 to $714 \mathrm{~g} / \mathrm{d}$, omasal flow of 
total $\mathrm{N}$ also responded linearly (from 584 to $710 \mathrm{~g} / \mathrm{d}$ ) in lactating dairy cows (Olmos Colmenero and Broderick, $2006 \mathrm{~b}$ ). The flow of $\mathrm{NH}_{3}-\mathrm{N}$ followed the concentration of fermentor $\mathrm{NH}_{3}-\mathrm{N}$ and tended to be higher with the herbage- versus the haylage-based diets; a significant forage $\times$ supplement interaction was also observed for this variable. Enhanced $\mathrm{N}$ input and $\mathrm{CP}$ digestibility possibly explain these results, as discussed in detail earlier. The flow of NAN was higher in herbage- versus haylage-based diets due to increased $\mathrm{N}$ input and bacterial $\mathrm{N}$ flow. A significant forage $\times$ supplement interaction was observed for NAN flow with haylage and BG and herbage and SB diets showing the lowest values. Because NAN flow is determined by subtracting $\mathrm{NH}_{3}-\mathrm{N}$ flow from total $\mathrm{N}$ flow, and feeding the haylage and $\mathrm{BG}$ and herbage and SB diets resulted in the highest $\mathrm{NH}_{3}-\mathrm{N}$ flow, it is not surprising that these 2 diets had the lowest NAN flow.

The flow of bacterial $\mathrm{N}$ was higher in fermentors fed herbage- rather than haylage-based diets (Table 4). Numerically higher concentrations of starch (mean $=4.0$ vs. $3.35 \%)$, WSC $($ mean $=10.1$ vs. $6.2 \%)$, and ethanol-soluble carbohydrates $($ mean $=6.0$ vs. $4.0 \%$ ) in herbage- versus haylage-based diets possibly explain the increased flow of bacterial N. Berthiaume et al. (2010), feeding high- versus low-NSC alfalfa to continuous-culture fermentors, observed a significant increase in bacterial $\mathrm{N}$ flow using ${ }^{15} \mathrm{~N}$ as the bacterial marker. Enhanced ruminal supply of fermentable energy (i.e., starch plus sugars) also resulted in increased omasal flow of bacterial NAN in late-lactation dairy cows fed high-NSC (p.m.-cutting) rather than low-NSC (a.m.-cutting) alfalfa baleage (Brito et al., 2009). In addition to enhanced supply of starch and sugars, the supply of RDP-N was also higher in herbage- versus haylage-based diets (Table 4). Concentration of $\mathrm{NH}_{3}-\mathrm{N}$ was well above the minimum ( 5 to $8.5 \mathrm{mg}$ of $\mathrm{NH}_{3}-\mathrm{N}$ / $\mathrm{dL}$ ) required to stimulate bacterial growth in vitro (Satter and Slyter, 1974) and in vivo (Kang-Meznarich and Broderick, 1980), whereas OM truly digested was similar across diets, thus suggesting that neither $\mathrm{NH}_{3}-\mathrm{N}$ nor fermentable OM limited bacterial protein synthesis. However, it is well documented that supplying RDP as free AA, peptides, or soluble proteins increases bacterial growth or fiber digestion, or both (Argyle and Baldwin, 1989; Griswold et al., 1996; Atasoglu et al., 1999; Carro and Miller, 1999). For instance, omasal flow of bacterial NAN increased by an average $14 \%$ when lactating dairy cows were fed true protein sources (i.e., soybean meal, cottonseed meal, and canola meal) versus urea (Brito et al., 2007).

Efficiency of bacterial protein synthesis, expressed in grams of bacterial $\mathrm{N}$ per kilogram of $\mathrm{DM}$ or $\mathrm{OM}$ truly digested in the rumen, was significantly higher in fermentors fed herbage- than in those fed haylagebased diets (Table 4). As discussed above, neither $\mathrm{NH}_{3}-\mathrm{N}$ nor fermentable $\mathrm{OM}$ appeared to have limited bacterial growth. Thus, enhanced bacterial efficiency with herbage-based diets may be related to enhanced supply of fermentable energy from NSC (i.e., starch plus WSC). The supply of RDP-N was $23 \%$ higher in herbage- versus haylage-based diets, possibly delivering more AA, peptides, and soluble protein to bacterial use. Compared with ruminal bacteria from cows fed urea, ruminal bacteria from cows fed true protein sources incorporated more $\mathrm{N}$ from NAN sources, presumably AA and peptides, resulting in increased bacterial NAN flow and efficiency (grams of bacterial $\mathrm{N}$ per kilogram of OM truly digested in the rumen; Brito et al., 2007).

\section{CONCLUSIONS}

Supplementation of herbage-based and haylagebased diets with 7-d SB increased true and apparent DM digestibility marginally (3 percentage units); however, it had no effect on fiber or $\mathrm{CP}$ digestibility, $\mathrm{CH}_{4}$ output, and bacterial efficiency. The small increase in digestibility coupled with the DM yield loss associated with sprouting barley could result in less digestible energy available to the animal and negative effects on animal performance when supplementing with highquality herbage diets, such as herbage or haylage. In this study, haylage-based diets produced $27 \%$ more $\mathrm{CH}_{4}$ per day compared with herbage-based diets, indicating the possibility of feeding high-quality herbage to mitigate $\mathrm{CH}_{4}$, compared with conserved forages. Further in vivo studies are required to evaluate the effects of SB supplementation of herbage-based diets on animal performance and to evaluate the economic and environmental sustainably of implementing sprouting technology on farms.

\section{ACKNOWLEDGMENTS}

The authors thank J. Everhart and R. Stout (USDAAgricultural Research Service, University Park, PA) for laboratory expertise and time contributed to conducting this experiment.

\section{REFERENCES}

Al-Karaki, G. N., and M. Al-Hashimi. 2012. Green fodder production and water use efficiency of some forage crops under hydroponic conditions. ISRN Agronomy 2012:924672. http://dx.doi. org/10.5402/2012/924672.

Anderson, A. 2009. Yummy sprouts for dairy cows. Progressive Dairyman. Accessed Apr. 4, 2014. http://www.progressivedairy.com/ index.php?option $=$ com_content $\&$ view $=$ article\&id $=3082$ :yummysprouts-for-dairy-cows\&catid=48:new-technology\&Itemid $=74$.

AOAC International. 2006. Official Methods of Analysis. 18th ed. AOAC International, Gaithersburg, MD. 
Argyle, J. L., and R. L. Baldwin. 1989. Effects of amino acids and peptides on rumen microbial yields. J. Dairy Sci. 72:2017-2027.

Atasoglu, C., C. Valdés, C. J. Newbold, and R. J. Wallace. 1999. Influence of peptides and amino acids on fermentation rate and de novo synthesis of amino acids by mixed micro-organisms from the sheep rumen. Br. J. Nutr. 81:307-314.

Bach, A., I. K. Yoon, M. D. Stern, H. G. Jung, and H. Chester-Jones. 1999. Effects of type of carbohydrate supplementation to lush pastures on microbial fermentation in continuous culture. J. Dairy Sci. $82: 153-160$.

Bargo, F., L. D. Muller, E. S. Kolver, and J. E. Delahoy. 2003b. Invited review: Production and digestion of supplemented dairy cows on pasture. J. Dairy Sci. 86:1-42.

Bargo, F., G. A. Varga, L. D. Muller, and E. S. Kolver. 2003a. Pasture intake and substitution rate effects on nutrient digestion and nitrogen metabolism during continuous culture fermentation. J. Dairy Sci. 86:1330-1340.

Berthiaume, R., C. Benchaar, A. V. Chaves, G. F. Tremblay, Y. Castonguay, A. Bertrand, G. Bélanger, R. Michaud, C. Lafrenière, T. A. McAllister, and A. F. Brito. 2010. Effects of nonstructural carbohydrate concentration in alfalfa on fermentation and microbial protein synthesis in continuous culture. J. Dairy Sci. 93:693-700.

Boadi, D., C. Benchaar, J. Chiquette, and D. Masse. 2004. Mitigation strategies to reduce enteric methane emissions from dairy cows: Update review. Can. J. Anim. Sci. 84:319-335.

Brito, A. F., G. A. Broderick, and S. M. Reynal. 2007. Effects of different protein supplements on omasal nutrient flow and microbial protein synthesis in lactating dairy cows. J. Dairy Sci. 90:18281841.

Brito, A. F., G. F. Tremblay, H. Lapierre, A. Bertrand, Y. Castonguay, G. Belanger, R. Michaud, C. Benchaar, D. R. Ouellet, and R. Berthiaume. 2009. Alfalfa cut at sundown and harvested as baleage increases bacterial protein synthesis in late-lactation dairy cows. J. Dairy Sci. 92:1092-1107.

Carro, M. D., and E. L. Miller. 1999. Effect of supplementing a fibre basal diet with different nitrogen forms on ruminal fermentation and microbial growth in an in vitro semi-continuous culture system (RUSITEC). Br. J. Nutr. 82:149-157.

Chavan, J. K., and S. S. Kadam. 1989. Nutritional improvement of cereals by sprouting. Crit. Rev. Food Sci. Nutr. 28:401-437.

Chung, T. Y., E. N. Nwokolo, and J. S. Sim. 1989. Compositional and digestibility changes in sprouted barley and canola seeds. Plant Foods Hum. Nutr. 39:267-278.

Coblentz, W. K., I. E. O. Abdelgadir, R. C. Cochran, J. O. Fritz, W. H. Fick, K. C. Olson, and J. E. Turner. 1999. Degradability of forage proteins by in situ and in vitro enzymatic methods. J. Dairy Sci. 82:343-354.

de Veth, M. J., and E. S. Kolver. 2001. Digestion of ryegrass pasture in response to change in $\mathrm{pH}$ in continuous culture. J. Dairy Sci. 84:1449-1457.

Dung, D. D., I. R. Godwin, and J. V. Nolan. 2010a. Nutrient content and in sacco digestibility of barley grain and sprouted barley. J. Anim. Vet. Adv. 9:2485-2492.

Dung, D. D., I. R. Godwin, and J. V. Nolan. 2010b. Digestive characteristics, ammonia nitrogen and volatile fatty acids levels, in sheep fed oaten chaff supplemented with Grimmett barley grain, freezedried or fresh barley sprouts. J. Anim. Vet. Adv. 9:2492-2501.

Fayed, A. M. 2011. Comparative study and feed evaluation of sprouted barley grains on rice straw versus Tamarix mannifera on performance of growing Barki lambs in Sinai. J. Am. Sci. 7:954-961.

Fazaeli, H., H. A. Golmohammadi, S. N. Tabatabayee, and M. AsghariTabrizi. 2012. Productivity and nutritive value of barley green fodder yield in hydroponic system. World Appl. Sci. J. 16:531-539.

Feng, P., C. W. Hunt, G. T. Pritchard, and S. M. Parish. 1995. Effect of barley variety and dietary barley content on digestive function on beef steers fed grass hay-based diets. J. Anim. Sci. 73:34763484 .

Getachew, G., P. H. Robinson, E. J. DePeters, S. J. Taylor, D. D. Gisi, G. E. Higginbotham, and T. J. Riordan. 2005. Methane production from commercial dairy rations estimated using an in vitro gas technique. Anim. Feed Sci. Technol. 123-124:391-402.
Griffin, T., Z. Conrad, C. Peters, R. Ridberg, and E. P. Tyler. 2014 Regional self-reliance of the Northeast food system. Renew. Agric. Food Syst. http://dx.doi.org/10.1017/S1742170514000027.

Griswold, K. E., W. H. Hoover, T. K. Miller, and W. V. Thayne. 1996. Effect of form of nitrogen on ruminal microbes in continuous culture. J. Anim. Sci. 74:483-491.

Hall, M. B., W. H. Hoover, J. P. Jennings, and T. K. Miller Webster. 1999. A method for partitioning neutral detergent-soluble carbohydrates. J. Sci. Food Agric. 79:2079-2086.

Hillier, R. J., and T. W. Perry. 1969. Effect of hydroponically produced oat grass on ration digestibility of cattle. J. Anim. Sci 29:783-785.

Hoover, W. H., T. K. Miller, S. R. Stokes, and W. V. Thayne. 1989 Effects of fish meals on rumen bacterial fermentation in continuous culture. J. Dairy Sci. 72:2991-2998.

Johnson, M. C., A. A. Devine, J. C. Ellis, A. M. Grunden, and V. Fellner. 2009. Effects of antibiotics and oil on microbial profiles and fermentation in mixed cultures of ruminal microorganisms. J. Dairy Sci. 92:4467-4480.

Kang-Meznarich, J. H., and G. A. Broderick. 1980. Effects of incremental urea supplementation on ruminal ammonia concentration and bacterial protein formation. J. Anim. Sci. 51:422-431.

Krehbiel, C. R., C. L. Ferrell, and H. C. Freetly. 1998. Effects of frequency of supplementation on dry matter intake and net portal and hepatic flux of nutrients in the mature ewe that consumes low-quality forage. J. Anim. Sci. 76:2464-2473.

Kung, L., Jr., E. C. Stough, E. E. McDonell, R. J. Schmidt, M. W. Hofherr, L. J. Reich, and C. M. Klingerman. 2010. The effect of wide swathing on wilting times and nutritive value of alfalfa haylage. J. Dairy Sci. 93:1770-1773.

McCollum, F. T., and M. L. Galyean. 1985. Influence of cottonseed meal supplementation on voluntary intake, rumen fermentation and rate of passage of prairie hay in beef steers. J. Anim. Sci. 60:570-577.

Moss, A. R., J. Jouany, and J. Newbold. 2000. Methane production by ruminants: Its contribution to global warming. Ann. Zootech. 49:231-253.

NRC. 2001. Nutrient Requirements of Dairy Cattle. 7th rev. ed. Natl. Acad. Press, Washington, DC.

Nickerson, C., R. Ebel, A. Borchers, and F. Carriazo. 2011. Major uses of land in the United States, 2007. U.S. Department of Agriculture. Economic Information Bulletin No. EIB-89. USDA Economic Research Service, Washington, DC.

O'Neill, B. F., M. H. Deighton, B. M. O'Loughlin, N. Galvin, M. O'Donovan, and E. Lewis. 2012. The effects of supplementing grazing dairy cows with partial amazed ration on enteric methane emissions and milk production during mid to late lactation. J. Dairy Sci. 95:6582-6590.

O'Neill, B. F., M. H. Deighton, B. M. O'Loughlin, F. J. Mulligan, T. M. Boland, M. O'Donovan, and E. Lewis. 2011. Effects of a perennial ryegrass diet or total mixed ration diet offered to springcalving Holstein-Friesian dairy cows on methane emissions, dry matter intake, and milk production. J. Dairy Sci. 94:1941-1951.

Olmos Colmenero, J. J., and G. A. Broderick. 2006a. Effect of dietary crude protein concentration on milk production and nitrogen utilization in lactating dairy cows. J. Dairy Sci. 89:1704-1712.

Olmos Colmenero, J. J., and G. A. Broderick. 2006b. Effect of dietary crude protein concentration on ruminal nitrogen metabolism in lactating dairy cows. J. Dairy Sci. 89:1694-1703.

Peer, D. J., and S. Leeson. 1985. Nutrient content of hydroponically sprouted barley. Anim. Feed Sci. Technol. 13:191-202.

Pond, K. R., W. C. Ellis, and D. E. Akin. 1984. Ingestive mastication and fragmentation of forages. J. Anim. Sci. 58:1567-1574.

Rodríguez, S. 2012. Hydroponic green fodder and ecology. Page 45-51 in Proc. Second International Symposium on Soilless Culture and Hydroponics. Acta Horticulturae 947. Int. Soc. Hortic. Sci., Leuven, Belgium.

Rodríguez-Muela, C., H. E. Rodríguez, O. Ruiz, A. Flores, J. A. Grado, and C. Arzola. 2005. Use of green fodder produced in hydroponics systems as supplement for Salers lactating cows during the dry season. Page 271-274 in Proc. Western Section, American 
Society of Animal Science, Las Cruces, NM. Am. Soc. Anim. Sci., Champaign, IL.

Satter, L. D., and L. L. Slyter. 1974. Effect of ammonia concentration on rumen microbial protein production in vitro. Br. J. Nutr. 32:199-208.

Sergeant, D. J. 2012. Sprouted barley fodder a blessing for NY farm. Lancaster Farming. Accessed Apr. 4, 2014. http://lancasterfarming. $\mathrm{com} /$ news/northeedition/Sprouted-Barley-Fodder-a-Blessing-forNY-Farm-\#.UFyfQo2PV_U.

Shibata, M., and F. Terada. 2010. Factors affecting methane production and mitigation in ruminants. Anim. Sci. J. 81:2-10.

Sneath, R., and F. McIntosh. 2003. Review of hydroponic fodder production for beef cattle. Meat and Livestock Australia, North Sydney, Australia.

Soder, K. J., A. F. Brito, and M. D. Rubano. 2012. Effect of incremental flaxseed supplementation of an herbage diet on methane output and ruminal fermentation in continuous culture. J. Dairy Sci. 95:3961-3969.

Soder, K. J., A. F. Brito, and M. D. Rubano. 2013. Effect of supplementing orchard grass herbage with a total mixed ration or flaxseed on fermentation profile and bacterial protein synthesis in continuous culture. J. Dairy Sci. 96:3228-3237.

Stokes, S. R., W. H. Hoover, T. K. Miller, and R. P. Manski. 1991. Impact of carbohydrate and protein levels on bacterial metabolism in continuous culture. J. Dairy Sci. 74:860-870.

Thomas, J. W., and B. S. Reddy. 1962. Sprouted oats as a feed for dairy cows. Quarterly Bull. Michigan Agric. Exp. Stat. 44:654655 .
Tudor, G. D., T. Darcy, P. C. Smith, F. Shallcross, and J. G. Allen. 2003. Is there a role for hydroponics in the beef industry? Page 333 of Proc. 25th Biennial Australian Society of Animal Production, Melbourne, Australia. Aust. Soc. Anim. Prod., Wagga Wagga, NSW, Australia.

USDA-ERS. 2011. Feed grains: Yearbook tables. Economic Research Service, USDA, Washington, DC. Accessed Apr. 4, 2014. http://www. ers.usda.gov/data-products/feed-grains-database/feed-grainsyearbook-tables.aspx\#.VA8rW8KwKhU.

Van Soest, P. J., J. B. Robertson, and B. A. Lewis. 1991. Methods for dietary fiber, neutral detergent fiber, and nonstarch polysaccharides in relation to animal nutrition. J. Dairy Sci. 74:3583-3597.

Vibart, R. E., S. P. Washburn, V. Fellner, M. H. Poore, J. T. Green Jr., and C. Brownie. 2007. Varying endophyte status and energy supplementation of fresh tall fescue in continuous culture. Anim. Feed Sci. Technol. 132:123-136.

Wales, W. J., E. S. Kolver, and A. R. Egan. 2009. Digestion during continuous culture fermentation when replacing perennial ryegrass with barley and steam-flaked corn. J. Dairy Sci. 92:189-196.

Weller, R. A., and A. F. Pilgrim. 1974. Passage of protozoa and volatile fatty acids from the rumen of the sheep and from a continuous in vitro fermentation system. Br. J. Nutr. 32:341-351.

Yang, C.-M. J., and G. A. Varga. 1989. Effect of three concentrate feeding frequencies on rumen protozoa, rumen digesta kinetics, and milk yields in dairy cows. J. Dairy Sci. 72:950-957.

Zinn, R. A., and F. N. Owens. 1986. A rapid procedure for purine measurement and its use for estimating net ruminal protein synthesis. Can. J. Anim. Sci. 66:157-166. 